\title{
Bruk av diuretika ved nyresykdom
}

\begin{abstract}
BAKGRUNN Diuretika er en viktig del av behandlingen ved en rekke indremedisinske tilstander, som hjertesvikt, leversvikt, nyresvikt og hypertensjon. I denne artikkelen presenteres oppdatert kunnskap om bruk av diuretika ved nyresykdom.
\end{abstract}

KUNNSKAPSGRUNNLAG Artikkelen bygger på litteratursøk i PubMed, kunnskap hentet fra lærebøker i nyrefysiologi og nyresykdommer samt forfatternes kliniske erfaring.

RESULTATER Nyresykdom påvirker diuretikas farmakokinetikk og farmakodynamikk, noe som må tas hensyn til ved valg og dosering av medikament. Dette gjelder spesielt ved nefrotisk syndrom og alvorlig kronisk nyresykdom (GFR $<30 \mathrm{ml} / \mathrm{min} / 1,73 \mathrm{~m}^{2}$ ).

FORTOLKNING Kunnskap om diuretikas farmakologi er avgjørende for rasjonell bruk ved nyresykdom. Dosetitrering under nøye klinisk oppfølging og optimalt doseintervall gir mulighet for å finne lavest mulige effektiv dose og redusere forekomsten av bivirkninger.

De fleste nyresykdommer karakteriseres av salt- og vannretensjon, noe som igjen fører til hypertensjon og ødemer. Diuretika er derfor en sentral del av behandlingen. Forekomsten av kronisk nyresykdom i befolkningen er høy, for stadium 3-5 (glomerulær filtrasjonsrate (GFR) $<60 \mathrm{ml} / \mathrm{min} / 1,73 \mathrm{~m}^{2}$ ) er den på 4-5\% (1). Diuretikas farmakokinetikk og -dynamikk endres ved nyresykdom. Eksempelvis må furosemiddosen ofte økes betydelig for å ha effekt ved lav glomerulær filtrasjonsrate, mens det motsatte gjelder de fleste andre medikamenter som utskilles i nyrene.

Med denne artikkelen ønsker vi å dele kunnskap om bruk og dosering av diuretika ved nyresykdom for å bidra til rasjonell behandling.

Slyngediuretika er mest brukt der det er ødemer og andre tegn til overhydrering. Tiazider og tiazidliknende diuretika er sentrale i behandling av hypertensjon hos pasienter med bevart nyrefunksjon, men kan også være nyttige hos pasienter med nyresykdom. Aldosteronantagonister og andre kaliumsparende diuretika omtales i mindre grad, da disse har begrenset plass i nyremedisinen. I ramme 1 gis en oversikt over diuretika som er markedsført i Norge.

\section{Kunnskapsgrunnlag}

Vi gjorde litteratursøk i PubMed, uten begrensning bakover i tid og avsluttet 1.11. 2013, med søkeordene «loop diuretics», «thiazides», «kidney disease», «nephrotic syndrome» og «pharmacology». For å få med relevante artikler brukte vi også referanselistene til sentrale oversiktsartikler publisert i høyt rangerte tidsskrifter. Det er supplert med læreverk innen nyresykdommer, internasjonale retningslinjer samt vår kliniske erfaring.

\section{Nyrefysiologi, virkemåte og virkested for diuretika}

Blodgjennomstrømmingen i nyrene er normalt omkring $1000 \mathrm{ml} / \mathrm{min}$ og glomerulær filtrasjonsrate (GFR) på omkring $100 \mathrm{ml} / \mathrm{min}$ $1,73 \mathrm{~m}^{2}$, hvilket betyr at en tidel av blodvolumet til enhver tid filtreres over glomerulusbasalmembranen og når tubulussystemet. Det aller meste reabsorberes, slik at kun 1\% av filtrert $\mathrm{NaCl}$ og vann skilles ut i urinen.

Figur 1 gir oversikt over tubulussystemet, fordeling av natriumreabsorpsjonen $\mathrm{i}$ de ulike segmenter og virkested for ulike typer diuretika. Slyngediuretika virker i den tykke, oppadstigende del av Henles sløyfe ved å blokkere pumper som reabsorberer natrium, kalium og klor. Normalt reabsorberes omkring $20 \%$ av filtrert natrium i dette området. Det betyr at dersom denne natriumreabsorpsjonen blokkeres, kan andelen filtrert natrium som skilles ut økes fra vanligvis $1 \%$ til $20 \%$.

Tiazider virker i distale tubuli ved å blokkere en pumpe som reabsorberer natrium og klor. Omkring $5 \%$ av filtrert natrium reabsorberes her. Kaliumsparende diuretika virker på samlerør der vanligvis kun $1-2 \%$ av filtrert natrium reabsorberes.

Amilorid blokkerer den epiteliale natriumkanalen og dermed reabsorpsjonen av natrium. Spironolakton og eplerenon virker ved kompetitiv hemming av intracellulære aldosteronreseptorer, slik at antall og funksjon av epiteliale natriumkanaler reduseres.

En betydelig større andel av $\mathrm{NaCl}$ og dermed vann reabsorberes altså i tykke, oppadstigende del av Henles sløyfe enn i distale tubuli og samlerør. Dette forklarer hvorfor maksimal diuretisk effekt er betydelig større for slyngediuretika enn for tiazider og kaliumsparende diuretika.

\section{Farmakokinetikk}

Farmakokinetikken beskriver sammenhengen mellom dose og konsentrasjon ved målorganet som et resultat av absorpsjon, distribusjon og eliminasjon. Det er store variasjoner i biotilgjengelighet, metabolisme og halveringstid mellom hovedgrupper av diu-

\section{Lene Heramb}

lene.heramb@stolav.no

Avdeling for nyresykdommer

St. Olavs hospital

\section{Stein Hallan}

Knut Aasarød

Avdeling for nyresykdommer

St. Olavs hospital

og

Institutt for kreftforskning og molekylær medisin Det medisinske fakultet

Norges teknisk-naturvitenskapelige universite

Se også kunnskapsprøve på www.tidsskriftet.no

\section{HOVEDBUDSKAP}

Farmakokinetikken endres ved fallende glomerulær filtrasjonsrate (GFR). Det gjør at slyngediuretikadosen ofte må økes

Ved nefrotisk syndrom endres diuretikas farmakokinetikk og farmakodynamikk slik at $ø$ kt dose, hyppigere dosering og tillegg av tiazid kan bli nødvendig

Ototoksisitet og hudreaksjoner forekommer ved bruk av høye doser slyngediuretika 
retika og innenfor hver gruppe. Tabell 1 $(2-4)$ gir en oversikt over dette.

Bumetanid peroralt absorberes praktisk talt komplett. Furosemid, derimot, har sterkt variabel absorpsjon, både mellom individer og fra dose til dose hos samme individ. Biotilgjengeligheten er i gjennomsnitt $50 \%$, men varierer fra $10 \%$ til $100 \%$ (5). Samtidig inntak av mat reduserer absorpsjonen av furosemid med $30 \%(6,7)$, men har liten effekt på absorpsjonen av bumetanid (7).

Ved hjertesvikt og leversvikt er absorpsjonen av furosemid forsinket, men den totale mengden absorbert medikament er som hos friske (8). Furosemid elimineres primært via nyrene. Halveringstiden er 1,5 timer, men den øker ved avtakende glomerulær filtrasjonsrate. Bumetanid metaboliseres hovedsakelig i leveren. Halveringstiden er en time, og den øker bare i liten grad ved lav glomerulær filtrasjonsrate. Dette forklarer at forholdet mellom ekvipotente doser furosemid og bumetanid endres fra $40: 1$ hos nyrefriske til $20: 1$ der det er alvorlig nyresvikt (9).

Slyngediuretika og tiazider virker på reseptorer på luminal side i tubuli. Det betyr at virkestoffet må nå urinen for å ha effekt, men preparatene er sterkt proteinbundne ( $>95 \%$ ), slik at ubetydelige mengder filtreres. Slyngediuretika og tiazider sekreteres i stedet aktivt fra blodbanen via tubuluscellene til lumen ved hjelp av transportproteiner for organiske syrer (10). Den tubulære transporten avtar med fallende glomerulær filtrasjonsrate. Årsaken er uavklart, men konkurranse om transportproteinene fra organiske syrer som hoper seg opp ved uremi kan spille en rolle (11). Resultatet er at pasienter med GFR $15 \mathrm{ml} / \mathrm{min} / 1,73 \mathrm{~m}^{2} \mathrm{kun}$ leverer $10-20 \%$ slyngediuretikum til «preurinen» i forhold til friske (12). Økt dose og dermed høyere serumnivå av diuretikum kan kompensere for dette. Ved GFR $15 \mathrm{ml} / \mathrm{min} /$ $1,73 \mathrm{~m}^{2}$ utløses maksimal respons med $160-200 \mathrm{mg}$ furosemid eller 4-5 mg bumetanid intravenøst (9). Tiaziddosen må på samme måte økes for å oppnå effektiv konsentrasjon i urinen ved nedsatt glomerulær filtrasjonsrate.

Nefrotisk syndrom karakteriseres av uttalt proteinuri, hypoalbuminemi og ødemer. Ved hypoalbuminemi øker distribusjonsvolumet, og mindre virkestoff blir tilgjengelig for sekresjon til lumen. Dessuten vil filtrert albumin i nyretubuli binde fritt diuretikum før det når virkestedet (13). Kun ubundet diuretikum virker på Na-K-2Cl-pumpen. Disse farmakokinetiske problemene kan avhjelpes ved å øke dosen og slik sikre adekvat mengde virkestoff ved reseptor.

\section{Farmakodynamikk}

Farmakodynamikken beskriver sammenhengen mellom konsentrasjon av medikamentet ved målorganet og responsen. Dose-responskurven for slyngediuretika og natriumutskil- ling er fremstilt i figur 2a (14). Dosen må over en terskelverdi for å utløse effekt. Deretter stiger kurven bratt inntil den når et platå med utskilling av ca. $20 \%$ av filtrert natrium. Hos friske gir $40 \mathrm{mg}$ furosemid eller $1 \mathrm{mg}$ bumetanid intravenøst maksimal respons. Slyngediuretikas farmakodynamikk endres ikke ved nedsatt glomerulær filtrasjonsrate. Gjenværende nefroner beholder normal respons på diuretika presentert ved reseptor, og maksimal fraksjon utskilt natrium $(\mathrm{FeNa})$ er omkring $20 \%$ - som hos friske (fig $2 \mathrm{a}$ ).

Det antas at de samme prinsippene gjelder for tiazider. Siden kun omkring $5 \%$ av filtrert natrium reabsorberes i distale tubuli, der tiazidene utøver sin effekt, er maksimal diuretisk respons tilsvarende lavere (12). Ved nefrotisk syndrom er maksimal respons på slyngediuretika nedsatt også når den måles i fraksjon utskilt natrium. Det samme gjelder ved andre ødematøse tilstander, som hjertesvikt og levercirrhose (15) (fig 2a). Mekanismene bak er dårlig forstått og trolig sammensatt (11)

\section{Diuretikaresistens}

Diuretikaresistens eller toleranse er i hovedsak beskrevet ved behandling med slyngediuretika og betegner avtakende respons på samme dose diuretikum ved bruk over tid. Fenomenet kan ses som et forsvar mot ska-

\section{RAMME 1}

Slyngediuretika: furosemid (Furix, Diural, Furosemid) og bumetanid (Burinex).

Tiazider: hydroklortiazid (Esidrex) og bendroflumetiazid (Centyl).

Aldosteronantagonister: spironolakton (Spirix, Aldactone) og eplerenon (Inspra).

Kombinasjoner: hydroklortiazid og amilorid (Moduretic mite, Normorix).

delig reduksjon av intravaskulært volum, men kan i klinikken være til hinder for å nå behandlingsmål. Akutt diuretikaresistens utløses sannsynligvis av hypovolemi (11, 12). Mekanismen er uklar, men resultatet er en intens natriumreabsorpsjon i etterkant av en dose slyngediuretikum (16). Dette understreker betydningen av saltrestriksjon og flere daglige doseringer av slyngediuretika.

Kronisk diuretikaresistens utvikles etter en tids behandling med slyngediuretikum. Det antas at høy saltbelastning gir hypertrofi av distale tubuli, slik at natriumreabsorpsjonen i dette segmentet øker (17-19). Tillegg av tiazider, som virker nettopp her,

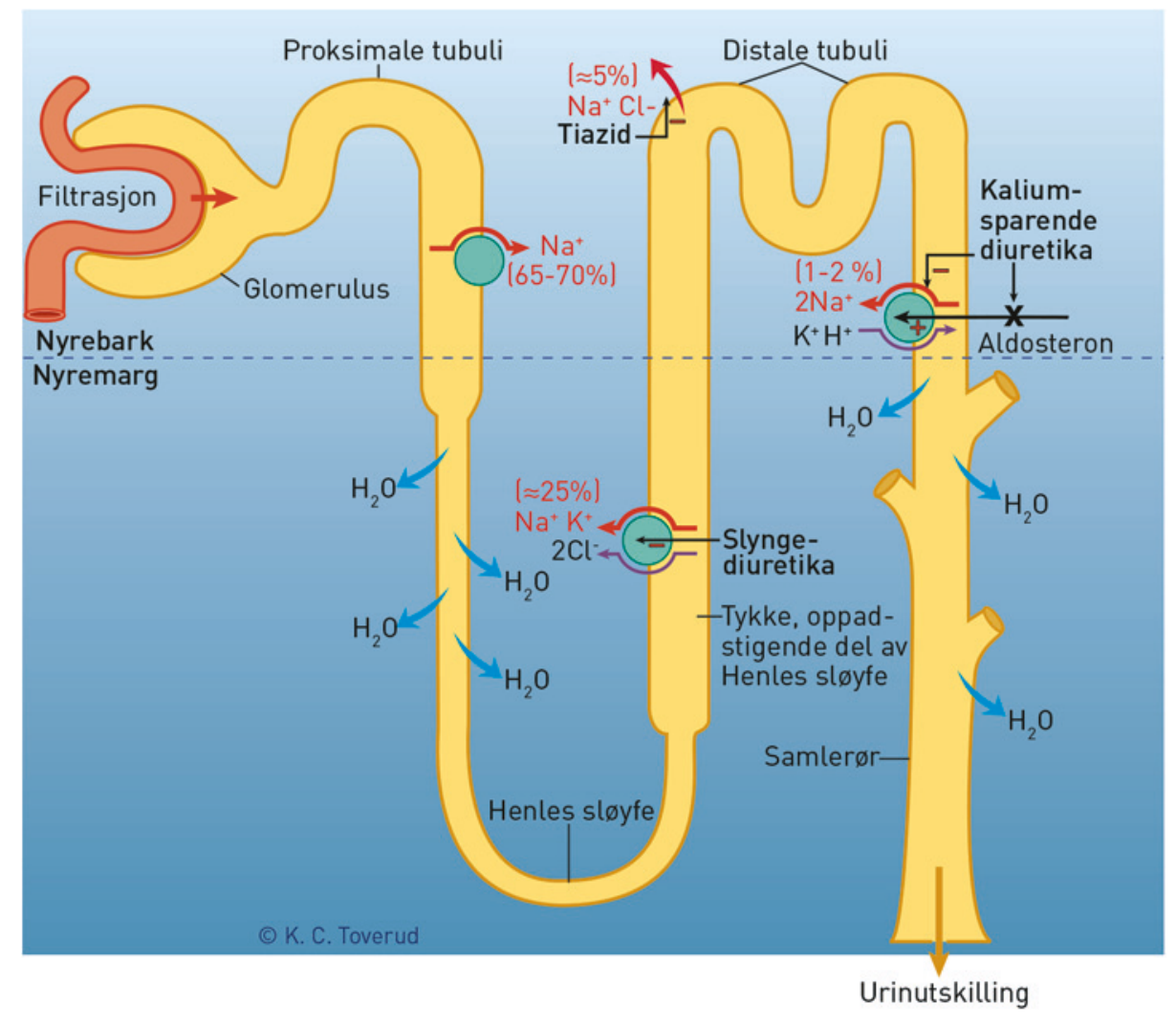

Figur 1 Oversikt over tubulussystemet med prosentvis fordeling av natriumreabsorpsjon i de ulike segmenter samt virkested for diuretika 
Tabell 1 Farmakokinetikk for diuretika

\begin{tabular}{|c|c|c|c|}
\hline Diuretikum & $\begin{array}{l}\text { Oral biotilgjenge- } \\
\text { lighet }(\%)\end{array}$ & $\begin{array}{l}\text { Halveringstid (t) } \\
\text { frisk }\end{array}$ & $\begin{array}{l}\text { Halveringstid }(\mathrm{t}) \\
\text { GFR }<30 \mathrm{ml} / \mathrm{min} / 1,73 \mathrm{~m}^{2}\end{array}$ \\
\hline Furosemid (2) & $10-100$ & $1,5-2$ & 2,8 \\
\hline Bumetanid (2) & $80-100$ & 1 & 1,6 \\
\hline Hydroklortiazid (3) & $65-75$ & 2,5 & $\emptyset \mathrm{kt}$ \\
\hline Bendroflumetiazid (3) & Data mangler & $2-5$ & Data mangler \\
\hline Spironolakton (4) & 90 & $\begin{array}{l}\text { 1,5. Aktive meta- } \\
\text { bolitter }>15\end{array}$ & Uendret \\
\hline Amilorid (4) & 50 & $17-26$ & 100 \\
\hline
\end{tabular}

kan i en slik situasjon være svært effektivt (fig 3) (12).

\section{Bivirkninger av slyngediuretika og tiazider}

Bvirkninger av diuretika er ofte et direkte resultat av medikamentenes effekt på nyrenes utskilling av elektrolytter og vann. Disse er doseavhengige og kan begrenses ved at man bruker så lav dose som mulig. Hypovolemi og prerenal nyresvikt kan oppstå i situasjoner med lavt væskeinntak. Både tiazider og slyngediuretika kan gi hypokalemi, hypomagnesemi og metabolsk alkalose.

Slyngediuretika gir økt kalsiumutskilling, noe som kan føre til sekundær hyperpara- tyreoidisme ved kronisk nyresykdom (20). Tiazider, derimot, reduserer kalsiumutskillingen, noe som kan utnyttes terapeutisk ved nyresteinsproblematikk (21). Hyponatremi er betydelig mer vanlig ved bruk av tiazider enn ved bruk av slyngediuretika. Det har sammenheng med at slyngediuretika i motsetning til tiazider reduserer evnen til å danne konsentrert urin.

Det er godt dokumentert at tiazider i behandlingen av hypertensjon er assosiert med glukoseintoleranse og dyslipidemi (22), men den kliniske betydningen er omdiskutert (3).

Enkelte bivirkninger av diuretika ses vesentlig hos pasienter med nyresykdom, da disse bruker høye doser. Slyngediuretika og tiazider har en fotosensibiliserende virkning og kan gi bulløst utslett på soleksponerte områder. Klinisk og histologisk likner tilstanden porphyria cutanea tarda, men mangler patologiske funn ved porfyrinanalyser i plasma, urin og feces (23). Behandling er seponering av medikament og beskyttelse mot sol.

Ototoksisitet er en velkjent bivirkning av slyngediuretika, best dokumentert for furosemid (24). Permanent døvhet er rapportert, men typisk er forbigående øresus og nedsatt hørsel. Både serumkonsentrasjon og infusjonsrate er av betydning. Samtidig behandling med aminoglykosid gir økt risiko. For å forebygge ototoksisitet bør anbefalte maksimaldoser og infusjonsrate respekteres. Doser på inntil $40 \mathrm{mg}$ kan gis langsomt i støt, mens høyere doser gis ufortynnet på infusjonspumpe eller blandes ut i $\mathrm{NaCl}$ og gis som infusjon over 2-4 timer.

\section{Diskusjon og anbefalinger}

Valg av slyngediuretikum

Furosemid kom først på markedet og er fortsatt mest brukt. Forskjellene i farmakokinetikk når det gjelder absorpsjon og metabolisme taler umiddelbart til fordel for bumetanid, ikke minst ved nyresykdom. Eksempelvis gjør dette midlets fullstendige absorpsjon at overgangen fra intravenøs til peroral behandling kan gjøres enkelt. $40 \mathrm{mg}$ furosemid intravenøst svarer til $1 \mathrm{mg}$ bume-
Fraksjon natriumekskresjon (\%)

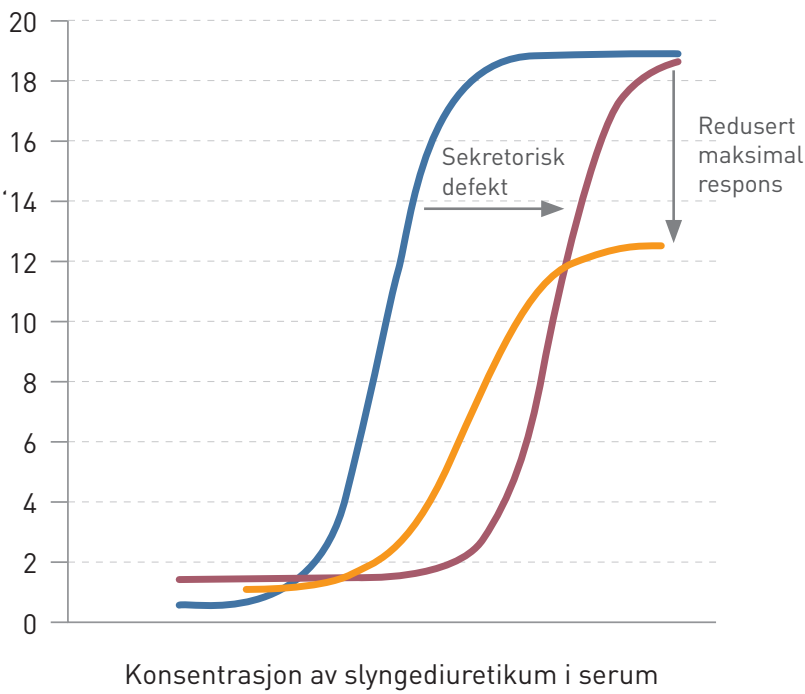

Absolutt natriumekskresjon, $\mathrm{mmol} / \mathrm{min}$

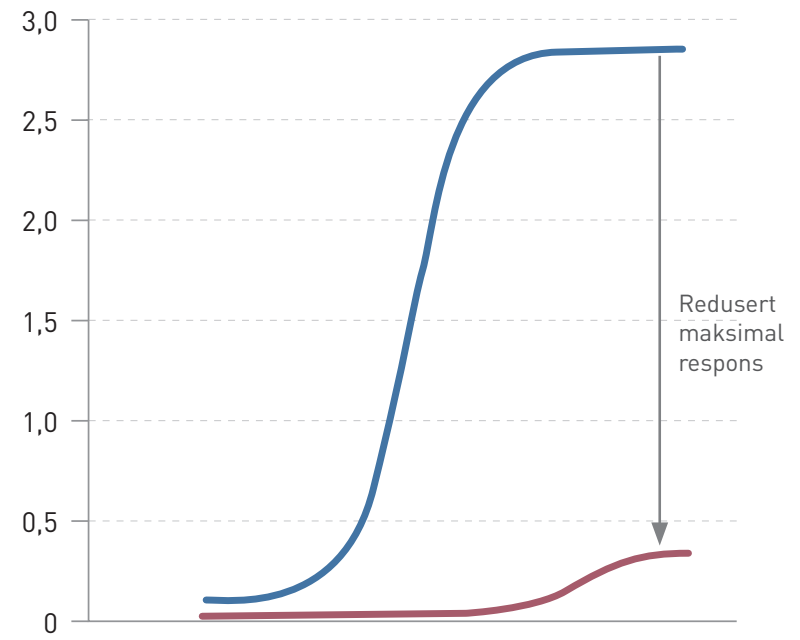

Konsentrasjon av slyngediuretikum i serum

Figur 2 Dose-respons-kurver for slyngediuretika. a) Fraksjon natriumekskresjon (FeNa) som en funksjon av serumkonsentrasjon av slyngediuretikum. Hos pasienter med nedsatt GFR er det nødvendig med høyere serumnivå av diuretikum for å oppnå høy nok konsentrasjon i urinen til å utløse maksimal respons. Maksimal respons er bevart når den uttrykkes som fraksjon utskilt natrium. Ved nefrotisk syndrom er det også endringer i farmakokinetikken som gjør det nødvendig med økt serumnivå av diuretikum for å oppnå maksimal effekt. Maksimal effekt ved nefrotisk syndrom er lavere enn hos friske. b) Absolutt natriumutskilling som funksjon av serumkonsentrasjon av slyngediuretikum. Den er betydelig nedsatt. Gjengitt med tillatelse fra Elsevier (14) 
tanid peroralt. For furosemid dobles dosen ved overgang til peroral behandling, men sterkt variabel absorpsjon gjør at effektiv dose ofte må titreres på nytt.

På den annen side kan rask og intens diurese etter inntak av slyngediuretikum være et problem og medføre dårlig etterlevelse. Furosemids langsomme absorpsjon og noe lengre halveringstid kan i denne sammenheng være gunstig. Ønsket om enkel dosering førte til utvikling av furosemid i retardform. Absorpsjonen er ufullstendig, og ved overgang til retardform må dosen økes med $50 \%$. Doser over $120 \mathrm{mg}$ er ikke anbefalt fra produsenten. Vi har god erfaring med bruk av furosemid i retardform, også hos pasienter med GFR $<30 \mathrm{ml} / \mathrm{min} / 1,73 \mathrm{~m}^{2}$.

Wargo \& Banta publiserte i 2009 en oversiktsartikkel med spørsmål om furosemid fortsatt skal være førstevalget blant slyngediuretika (25). De konkluderer med at torsemid, et slyngediuretikum med halveringstid 3-4 timer, har fordeler ved hjertesvikt. Medikamentet er imidlertid ikke markedsført i Norge. Ved andre ødemtilstander, inkludert nyresykdommer, finnes det ingen støtte i litteraturen for å foretrekke torsemid eller bumetanid fremfor furosemid. Det er likevel grunn til å tro at furosemids dårlige og variable biotilgjengelighet har kliniske konsekvenser for en del pasienter.

\section{Slyngediuretikuminfusjon}

Kontinuerlig infusjon er et alternativ for å sikre effektive mengder diuretikum ved virkestedet til enhver tid. Det er vist at en slik strategi øker total mengde utskilt natrium i forhold til intermitterende infusjon av tilsvarende totaldose (26), og at dette kan være klinisk nyttig ved for eksempel alvorlig hjertesvikt (27).

Ved oppstart må det gis bolusdose for å sikre at høy konsentrasjonen oppnås raskt. Ny bolusdose gis ved økning av dose. Tabell 2 (12) gir forslag til dosering ut fra nyrefunksjon (4). Effekten av startdosen evalueres etter omtrent en time, og ny bolusdose og økt infusjonstakt gis ved behov. Furosemid 40 $\mathrm{mg} / \mathrm{t}$ er tilstrekkelig til å gi vedvarende maksimal effekt, også ved betydelig nedsatt glomerulær filtrasjonsrate.

\section{Redusert glomerulær filtrasjonsrate}

Kronisk nyresykdom med nedsatt glomerulær filtrasjonsrate kan skyldes en rekke ulike sykdomsprosesser og karakteriseres av redusert antall fungerende nefroner. Ved alvorlig kronisk nyresykdom $\left(\mathrm{GFR}<30 \mathrm{ml} / \mathrm{min} / 1,73 \mathrm{~m}^{2}\right)$ ser man i økende grad kliniske tegn til væskeretensjon, som perifere ødemer, hypertensjon og i alvorlige tilfeller lungeødem. Slyngediuretika er førstevalget, og på grunn av nedsatt tubulær sekresjon av slyngediuretikum er høye doser ofte nødvendig.

Tabell 2 Dosering ved kontinuerlig infusjon av slyngediuretika. Merk: Før infusjonsraten økes gis en ny bolusdose (12)

$$
\text { Intravenøs startdose (mg) Infusjonshastighet (mg/t) }
$$

GFR $\left(\mathrm{ml} / \mathrm{min} / 1,73 \mathrm{~m}^{2}\right)$

\begin{tabular}{lcccc} 
& Alle nivåer & $<25$ & 25 til 75 & $>75$ \\
Furosemid & 40 & 20 så 40 & 10 så 20 & 10 \\
Bumetanid & 1 & 1 så 2 & 0,5 så 1 & 0,5 \\
\hline
\end{tabular}

Det er store individuelle forskjeller i respons på diuretika, også ved alvorlig kronisk nyresykdom. Startdosen kan være lav (furosemid $40 \mathrm{mg} \times 2$ peroralt) og må titreres opp i sprang på $50-100 \%$ av foregående dose ved behov. Behandlingen følges med kontroll av vekt, blodtrykk, elektrolytter og kreatininnivå. Lav glomerulær filtrasjonsrate betyr imidlertid at mengden natrium filtrert ut i nyretubuli, og dermed tilgjengelig for diuretikaeffekt, er tilsvarende lav. Selv maksimal respons gir derfor en beskjeden absolutt natriumutskilling (fig 2).

Maksimaldose furosemid peroralt angis av produsent til $2 \mathrm{~g}$ /døgn. I klinisk praksis er det vanlig å stanse ved $500 \mathrm{mg} \times 2$, da vil maksimal respons være nådd hos de aller fleste. Tilsvarende for bumetanid er $5-10 \mathrm{mg} \times 2$. Kombinasjon med tiazid kan gi økt natriurese også ved GFR $<30 \mathrm{ml} / \mathrm{min} / 1,73 \mathrm{~m}^{2}$. Tiazid må i så fall gis i høy dose, 100-200 mg hy-

Tykke, oppadstigende del av Henles sløyfe (slyngediuretikaeffekt)

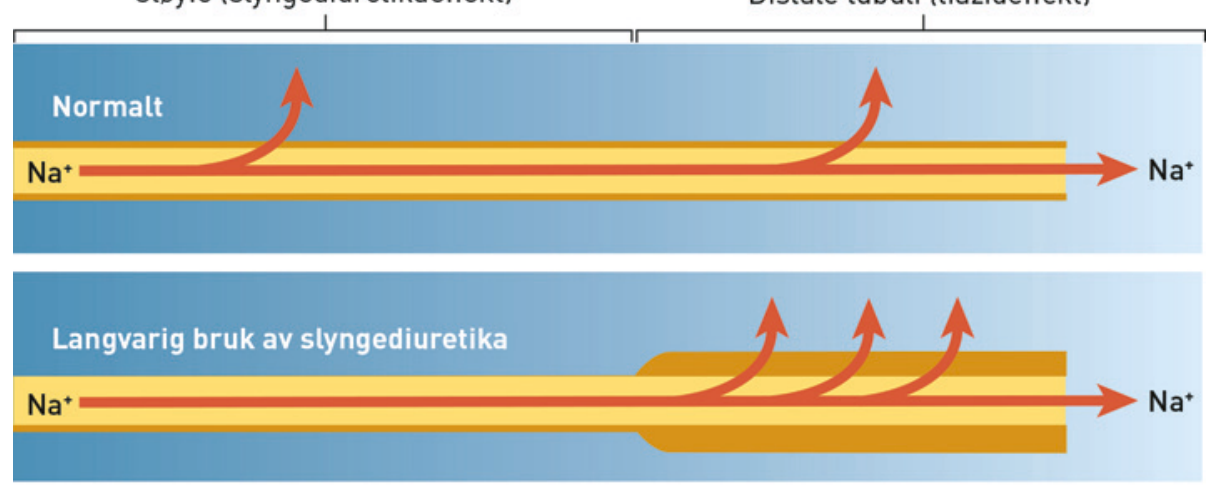

\section{Slyngediuretika og tiazid}

\section{$\mathrm{Na}^{+}$}

droklortiazid daglig, grunnet endringer i farmakokinetikk (28).

Langtidsbehandling med en slik kombinasjon er dårlig dokumentert, og da bruk av tiazid i høy dose er forbundet med betydelige metabolske bivirkninger, er kombinasjonsbehandling forbeholdt spesielle situasjoner. Det kan for eksempel være pasienter med terminal nyresvikt og overhydrering der dialyse er vurdert uegnet og man ikke kommer til mål med slyngediuretikum.

\section{Hypertensjon ved kronisk nyresykdom}

Det er en tett sammenheng mellom hypertensjon og kronisk nyresykdom, idet tilstandene gjensidig kan forårsake eller forsterke hverandre (29). Ved normal nyrefunksjon er det godt dokumentert at tiazider og tiazidliknende diuretika senker blodtrykket og gir redusert hypertensjonsrelatert mortalitet og morbiditet $(30,31)$. Dette synes også å gjelde 
ved kronisk nyresykdom med glomerulær filtrasjonsrate ned til $30 \mathrm{ml} / \mathrm{min} / 1,73 \mathrm{~m}^{2}$ (32).

I de fleste studier har man imidlertid brukt det tiazidliknende medikamentet klortalidon, som har lengre halveringstid enn hydroklortiazid og bendroflumetiazid. Klortalidon er ikke markedsført i Norge, og det er omdiskutert om resultatene kan overføres til bruk av tiazider, og i så fall i hvilken dose $(3,33)$.

Eldre studier indikerte at tiazider mister diuretisk og antihypertensiv effekt når den glomerulære filtrasjonsraten faller under $15-20 \mathrm{ml} / \mathrm{min} / 1,73 \mathrm{~m}^{2}$, og tiazider ble derfor ikke anbefalt ved GFR $<30 \mathrm{ml} / \mathrm{min} / 1,73 \mathrm{~m}^{2}$. I nyere artikler er det antydet at tiazider har antihypertensive egenskaper uavhengig av diuretisk effekt, blant annet via effekt på perifer motstand (34). Natriuretisk respons og antihypertensiv effekt var lik for furosemid og hydroklortiazid også ved GFR $25 \mathrm{ml} / \mathrm{min} /$ $1,73 \mathrm{~m}^{2}$ (35). Kombinasjonsbehandling med begge medikamenter hadde additiv effekt på natriurese og blodtrykk, men ga i motsetning til behandling med ett diuretikum signifikant fall i glomerulær filtrasjonsrate, som uttrykk for hypovolemi.

Retningslinjer utarbeidet av The International Society of Nephrology, KDIGO Guidelines, åpner derfor for å beholde tiazid i lavdose som en del av et antihypertensivt regime også ved GFR $<30 \mathrm{ml} / \mathrm{min} / 1,73 \mathrm{~m}^{2}$ (29). Vi har god erfaring med tilsvarende praksis. Ved ødemer eller dårlig kontrollert hypertensjon anbefales det å skifte til slyngediuretikum. Kombinasjonsbehandling ved hypertensjon er dårlig dokumentert og bør etter vår mening unngås på grunn av økt risiko for hypovolemi og elektrolyttforstyrrelser.

\section{Nefrotisk syndrom}

Ved nefrotisk syndrom er ACE-hemmer eller tilsvarende medikament samt salt- og væskerestriksjon viktige $\mathrm{i}$ behandlingen, men dette omtales ikke nærmere her. Et slyngediuretikum er som regel nødvendig for effekt på ødemer. Endringer i farmakokinetikk tilsier behov for høyere dose ved nefrotisk syndrom, men det kan likevel startes lavt (furosemid $40 \mathrm{mg} \times 2$ ). Ved normal nyrefunksjon er furosemid 80-120 mg intravenøst, furosemid 250 $\mathrm{mg}$ peroralt eller bumetanid $2-3 \mathrm{mg}$ peroralt tilstrekkelig til å utløse maksimal respons (12).

Bare ved samtidig redusert glomerulær filtrasjonsrate har det noen hensikt å gi høyere enkeltdoser. Ved behov kan behandlingen optimaliseres ved å dosere slyngediuretikum 3-4 ganger daglig og/eller legge til tiazid. Anbefalt dose er hydroklortiazid $50-100 \mathrm{mg} \times 1$ ved GFR $30-60 \mathrm{ml} / \mathrm{min} /$ $1,73 \mathrm{~m}^{2}$ og $100-200 \mathrm{mg}$ ved GFR $<30 \mathrm{ml} /$ $\mathrm{min} / 1,73 \mathrm{~m}^{2}(28,36)$.

\section{Lene Heramb (f. 1968)}

er spesialist i nyresykdommer og assistentlege. Forfatter har fylt ut ICMJE-skjemaet og oppgir ingen interessekonflikter.

\section{Stein Hallan (f. 1962)}

er dr.med., overlege og professor.

Forfatter har fylt ut ICMJE-skjemaet og oppgir ingen interessekonflikter.

\section{Knut Aasarød (f. 1950)}

er dr.med. og avdelingsoverlege.

Forfatter har fylt ut ICMJE-skjemaet og oppgir ingen interessekonflikter.

\section{Litteratur}

1. Hallan SI, Coresh J, Astor BC et al. International comparison of the relationship of chronic kidney disease prevalence and ESRD risk. J Am Soc Nephrol 2006; 17: 2275-84.

2. Shankar SS, Brater DC. Loop diuretics: from the $\mathrm{Na}-\mathrm{K}-2 \mathrm{Cl}$ transporter to clinical use. Am J Physio Renal Physiol 2003; 284: F11-21.

3. Ernst ME, Moser M. Use of diuretics in patients with hypertension. N Engl J Med 2009; 361: 2153-64.

4. Brater DC. Diuretic therapy. N Engl J Med 1998 339: 387-95.

5. Murray MD, Haag KM, Black PK et al. Variable furosemide absorption and poor predictability of response in elderly patients. Pharmacotherapy 1997; 17: 98-106

6. Beermann B, Midskov C. Reduced bioavailability and effect of furosemide given with food. Eur J Clin Pharmacol 1986; 29: 725-7.

7. McCrindle JL, Li Kam Wa TC, Barron W et al. Effect of food on the absorption of frusemide and bumetanide in man. Br J Clin Pharmacol 1996; 42: $743-6$.

8. Vargo DL, Kramer WG, Black PK et al. Bioavailability, pharmacokinetics, and pharmacodynamics of torsemide and furosemide in patients with congestive heart failure. Clin Pharmacol Ther 1995 57: 601-9.

9. Voelker JR, Cartwright-Brown D, Anderson S et al. Comparison of loop diuretics in patients with chronic renal insufficiency. Kidney Int 1987; 32: 572-8.

10. Odlind B, Beermann B. Renal tubular secretion and effects of furosemide. Clin Pharmacol Ther 1980; 27: 784-90

11. Sica DA. Diuretic use in renal disease. Nat Rev Nephrol 2012; 8: 100-9.

12. Brater DC. Update in diuretic therapy: clinical pharmacology. Semin Nephrol 2011; 31: 483-94.

13. Kirchner KA, Voelker JR, Brater DC. Intratubular albumin blunts the response to furosemide-A mechanism for diuretic resistance in the nephrotic syndrome. J Pharmacol Exp Ther 1990; 252: 1097-101.

14. Ellison DH. Seldin and Giebisch's The kidney physiology \& pathophysiology. Amsterdam: Elsevier, 2013.

15. Hebert RJ. Seldin and Giebisch' The Kidney \& pathophysiology. Amsterdam: Elsevier, 2008: 1427

16. Wilcox CS, Mitch WE, Kelly RA et al. Response of the kidney to furosemide. I. Effects of salt intake and renal compensation. J Lab Clin Med 1983; 102 $450-8$

17. Kaissling B, Stanton BA. Adaptation of distal tubule and collecting duct to increased sodium delivery. I. Ultrastructure. Am J Physiol 1988: 255: F1256-68

18. Stanton BA, Kaissling B. Adaptation of distal tubule and collecting duct to increased $\mathrm{Na}$ delivery. II. Na+ and K+ transport. Am J Physiol 1988. 255: F1269-75
19. Loon NR, Wilcox CS, Unwin RJ. Mechanism of impaired natriuretic response to furosemide during prolonged therapy. Kidney Int 1989; 36 : $682-9$

20. Isakova T, Anderson CA, Leonard MB et al. Diuretics, calciuria and secondary hyperparathyroidism in the Chronic Renal Insufficiency Cohort. Nephrol Dial Transplant 2011; 26: 1258-65.

21. Reilly RF, Peixoto AJ, Desir GV. The evidencebased use of thiazide diuretics in hypertension and nephrolithiasis. Clin J Am Soc Nephrol 2010; 5: 1893-903.

22. Palmer BF. Metabolic complications associated with use of diuretics. Semin Nephrol 2011; 31: 542-52.

23. Green JJ, Manders SM. Pseudoporphyria. J Am Acad Dermatol 2001; 44: 100-8.

24. Rybak LP. Pathophysiology of furosemide ototoxicity. J Otolaryngol 1982; 11: 127-33.

25. Wargo KA, Banta WM. A comprehensive review of the loop diuretics: should furosemide be first line? Ann Pharmacother 2009; 43: 1836-47.

26. Rudy DW, Voelker JR, Greene PK et al. Loop diuretics for chronic renal insufficiency: a continuous infusion is more efficacious than bolus therapy. Ann Intern Med 1991: 115: 360-6.

27. Dormans TP, van Meyel JJ, Gerlag PG et al. Diuretic efficacy of high dose furosemide in severe hear failure: bolus injection versus continuous infusion. J Am Coll Cardiol 1996: 28: 376-82.

28. Fliser D, Schröter M, Neubeck M et al. Coadministration of thiazides increases the efficacy of loop diuretics even in patients with advanced renal failure. Kidney Int 1994; 46: 482-8.

29. KDIGO Clinical Practice Guideline for the Management of Blood Pressure in Chronic Kidney Disease. Chapter 1: Introduction. Kidney Int Supp 2012; $2: 343-6$.

30. ALLHAT Officers and Coordinators for the ALLHAT Collaborative Research Group. The Antihypertensive and Lipid-Lowering Treatment to Prevent Heart Attack Trial. Major outcomes in high-risk hypertensive patients randomized to angiotensinconverting enzyme inhibitor or calcium channel blocker vs diuretic: The Antihypertensive and Lipid-Lowering Treatment to Prevent Heart Attack Trial (ALLHAT). JAMA 2002; 288: 2981-97.

31. Psaty BM, Smith NL, Siscovick DS et al. Health outcomes associated with antihypertensive therapies used as first-line agents. A systematic review and meta-analysis. JAMA 1997; 277: 739-45.

32. Rahman M, Pressel S, Davis BR et al. Cardiovascular outcomes in high-risk hypertensive patients stratified by baseline glomerular filtration rate. Ann Intern Med 2006; 144: 172-80.

33. Ernst ME, Mann SJ. Diuretics in the treatment of hypertension. Semin Nephrol 2011; 31: 495-502.

34. Karadsheh F. Weir MR. Thiazide and thiazide-like diuretics: an opportunity to reduce blood pressure in patients with advanced kidney disease. Curr Hypertens Rep 2012; 14: 416-20

35. Dussol B, Moussi-Frances J, Morange $S$ et al. A pilot study comparing furosemide and hydrochlorothiazide in patients with hypertension and stage 4 or 5 chronic kidney disease. J Clin Hyper tens (Greenwich) 2012; 14: 32-7

36. Knauf H, Mutschler E. Diuretic effectiveness of hydrochlorothiazide and furosemide alone and in combination in chronic renal failure. J Cardiovasc Pharmacol 1995; 26: 394-400.

Mottatt 29.5. 2013, første revisjon innsendt 14.10. 2013, godkjent 14.2. 2014. Redaktør: Sigurd Høye. 